\title{
Heredity of resistance to Sclerotinia sclerotiorum in sunflowers. II. - Study of capitulum resis- tance to natural and artificial ascospore infec- tions
}

Felicity VEAR \& Denis TOURVIEILLE DE LABROUHE

I.N.R.A., Station d'Amélioration des Plantes, Domaine de Crouelle, 63039 Clermont-Ferrand Cedex

Sunflower capitulum attacks resulting from infection by Sclerotinia sclerotiorum ascospores were observed under natural conditions with irrigation during flowering, and after contamination of florets with ascospore suspensions (ascospore test). The study was made on the parental inbred lines and F1 hybrids of a factorial cross of 6 male steriles and 6 restorers.

There were significant genetic differences in reactions to both natural and artificial infections. According to the hybrid combinations studied, the general combining ability/specific combining ability ratio varied between 4.06 and 0.87 for natural attack and between 4.49 and 2.74 for the ascospore test. Some interaction effects were significant.

The regressions between inbred lines and their hybrids were significant but much closer for the ascospore test $(r=0.83)$ than for natural infection $(r=0.49)$. The ascospore test was significantly correlated with natural infection $(r=-0.57)$ and it was concluded that this test may be used in breeding programmes for parents that will give hybrids with good levels of capitulum resistance under natural conditions.

Additional key words : Controls, factorial analysis, parental effects, interactions, heritability, additivity. au niveau du capitule à des infections naturelles et artificielles par ascospores.

Les infections de capitules de tournesol par les ascospores de Sclerotinia sclerotiorum sont obtenues en conditions naturelles grâce à une irrigation contrôlée durant la floraison et en contaminations artificielles en pulvérisant sur la face fertile une suspension de spores ("test ascospores").

Les études ont porté sur les hybrides (F1) et les lignées parentales d'un plan factoriel de croisement entre 6 mâle-stériles et 6 restaureurs. On observe des différences de comportement des génotypes dans les conditions d'infection naturelle ou artificielle. Selon les combinaisons étudiées, le rapport aptitude générale à la combinaison/aptitude spécifique à la combinaison varie de 4,06 à 0,87 pour les attaques naturelles et de 4,49 à 2,74 pour le « test ascospore ». Un certain nombre d'interactions significatives entre les lignées mâles et les lignées femelles sont observées. Les régressions entre les lignées parentales et leurs hybrides sont significatives, bien que meilleures pour le test ascospores $(r=0,83)$ que pour l'infection naturelle $(r=0,49)$.

Le test ascospores est corrélé de façon significative avec l'infection naturelle. Ce test est donc utilisable dans les programmes de sélection des lignées parentales aptes à donner des hybrides ayant un bon comportement vis-à-vis des attaques naturelles de Sclerotinia sur capitule.

Mots clés additionnels : Témoins, analyse factorielle, effets parentaux, interactions, héritabilité, additivité.

\section{INTRODUCTION}

Sclerotinia sclerotiorum (Lib.) De Bary. is an important parasite of sunflowers in many parts of the world.
It may attack roots, stems, leaves, buds and capitula according to environmental conditions. There are no effective chemical controls at present (LAMARQUE $e t$ al., 1985 ) and thus sunflower hybrids with satisfactory 
genetic resistance are required. Resistance is partial, polygenic and often differs in different parts of the plant (Thuault \& TourvieILle, 1988).

In France, important natural attacks do not occur every year and, in order to permit the breeding of sunflowers for resistance, several tests and observation methods have been developed (VEAR \& GuIllaumin, 1977 ; TOURVIEILLE \& VeAR, 1984 ; VeAr \& TOURVIEILLE, 1987). They measure resistance to different forms or stages of attack; their validity has been judged in comparison with natural Sclerotinia attacks on field trials. To determine the stages of breeding programmes at which these tests are most effective, studies of the heredity of the forms of resistance they measure have been carried out.

In a previous article (ROBERT et al., 1987) it was shown that the rate of extension of $S$. sclerotiorum mycelium on the dorsal surface of the capitulum (mycelium test) is heritable (mid parent-hybrid regression coefficient $R=1.11$ ) and largely additive. The correlation coefficient between parents and the mean of their hybrids attained $r=0.93$ for 35 hybrids and their parents. It is thus possible to use this test on early generations in breeding and to predict the values of hybrids from those of inbred lines.

A test of mycelium extension on young stems of the same genotypes also gave results indicating significant heritability $(R=0.84)$ but with greater variation. 'This test may indicate resistance to attack on terminal buds (Serieys in Vear \& TourvieILle, 1984b).

The mycelium test, although useful, determines resistance to only part of the infection cycle of $S$. sclerotiorum on sunflower capitula. It bypasses the entier phase of pathogen pollution and infection which occurs in the florets during flowering, more particularly during pollen production (SAYs-LeSAGE \& TourviEILLE, 1988).

A test involving application of ascospore suspensions on the floral surface (TourvieILLE \& VEAR, 1984) has the advantage of repeating quite closely the natural epidemiological cycle and permits measurement of resistance to the whole phase of parasite installation. It is thus complimentary to the mycelium test.

This paper reports studies of the heredity of resistance as measured by this test and, in addition, that determined from observations of natural attack.

\section{MATERIALS AND METHODS}

\section{A. Sunflower genotypes}

These were the same as those described by ROBERT et al., (1987), chosen to represent the known diversity of reaction to $S$. sclerotiorum :
- Six female parents : (1) B11A3, (2) 62, (3) SD, (4) $\mathrm{GH},(5) \mathrm{GU}$ et (6) F10. B11A3 and F10 have genic male sterility, the others cytoplasmic male sterility. The male fertile forms were used for tests and observations of the inbred lines.

- Six male parents : (1) HA 61, (2) Rha 274, (3) Rha 266, (4) V 135, (5) PACl, (6) PRS 5.

HA 61 and V 135 are male sterility maintainers, the others are restorer lines.

- 36 hybrids from a factorial cross of the parents. Two of these hybrids, well known for their reaction to Sclerotinia, served as controls.

Rémil : B11A3 × HA 61 - resistant,

CR 2: GH $\times$ Rha 266 - susceptible.

For the ascospore test 1 hybrid (F10 Rha 266) was lacking; for natural attacks 4 hybrids (GH Rha 274, F10 Rha 266, B11A3 VI35, SD VI35) were absent. Results were calculated without these genotypes except to obtain mean parental effects on hybrids, in which case theoretical missing plot results were calculated.

\section{B. S. sclerotiorum isolates}

\section{Ascospore test}

In the absence of any known sunflower S. sclerotiorum interaction (ThUAULT \& TOURVIELle, 1988 ), ascospores were obtained from sclerotia of various origins.

\section{Natural attacks}

The inoculum present in the field at JOzE (63) is entirely natural, favorised over the past 10 years by 3 sunflower crops irrigated at flowering.

\section{Ascospore test method}

This method was described by TourvieILLE \& VeAR (1984) and Vear \& TOURVIEILLE (1985). It consists of spraying $5 \mathrm{ml}$ of a suspension of 5 ascospores $/ \mathrm{mm}^{3}$ water onto the floral surface of sunflower capitula during the first half of flowering. The heads are then covered with sulphurised paper bags. Inoculations were made twice a week, each plant being inoculated once, at the correct stage. On each occasion, controls at the correct stage (obtained by staggered sowing dates) were inoculated to permit comparison between different dates and to eliminate climatic effects. For each genotype there were 2 blocks, each with 30 to 40 plants. Sprinklers provided approximately $12 \mathrm{~mm}$ water after each inoculation.

Observations were made twice a week from 2 weeks after inoculations, the dates of first symptoms of rot on the back of the capitulum on each plant were noted. For each genotype, a latency index (I) was calculated from the ratio :

$\mathrm{Nb}$ days between infections and symptom appearance for genotypes

$\mathrm{Nb}$. days infections - symptoms for controls inoculated at the same date 
This index thus increases with increasing resistance to Sclerotinia. The control data were means of results for Rémil and CR2, such that a genotype with an index of 1 is moderate, above 1 has good resistance, below 1 tends to susceptibility. In addition, the percentage of plants showing symptoms before complete maturity was calculated.

\section{Observations of natural attacks}

The trials were in randomised block designs, with 4 repetitions of 2 rows of 23 plants. The system of irrigation at flowering to favorize $S$. sclerotiorum attack was described by VEAR \& TOURVIEILlE (1987) : the trial is irrigated by sprinklers 3 days each week during flowering. As for the ascospore test, a control (Rémil) was sown at different dates in order to cover the flowering period of all genotypes. Observations were made of the percentages of plants per plot showing $S$. sclerotiorum symptoms at maturity. To take into account climatic differences the results are expressed as the ratio:

$\%$ plants attacked

$\%$ plants attacked for control with same flowering date

\section{E. Estimations of heritability}

1) Heritability in the sense of statistical additive effects was estimated from factorial analyses of variance measuring parental and interaction effects. The $F$ values of parental and interaction effects are compared and the ratio :

$$
\frac{\sigma^{2} \text { general combining ability }}{\sigma^{2} \text { specific combining ability }}
$$

was determined by the method described by ROBERT $e t$ al. (1987).

$$
\frac{\sigma^{2} \text { G.C.A. }}{\sigma^{2} \text { S.C.A. }}=
$$

(female mean square - interaction mean square) nb. rep $\times$ nb. males

+ male mean square - interaction mean square) nb. rep $\times$ nb. females

/ (interaction mean square - error mean square) nb. rep

2) Heritability in the sense of predictability between inbred lines and hybrids was assessed from regression and correlation coefficients between values for mid parents and hybrids and for inbred lines and the means of their hybrids.

\section{RESULTS}

\section{A. Ascospore test}

Maintenance of humid conditions favorable for $S$. sclerotiorum during and after the flowering resulted in very high percentages of plants showing symptoms before maturity: they vary among the inbred lines between $75 \%$ (HA 61) and $100 \%$ (62, F10 and V 135) with a mean of $93.1 \%$. For the hybrids, the extremes were $79.2 \%$ (B11A3 PAC1) and $100 \%$ (13 hybrids) with a mean of $95.9 \%$.

Although in both cases analyses of variance showed significant genotypic effects, these were very limited. For the inbred lines only HA61 differed from the genotypes with $100 \%$ infection and no line was significantly different from the mean. In the case of the hybrids, 10 genotypes differed significantly from those with $100 \%$ infection but only B11A3 $\times$ PACl was significantly less infected than the mean.

The results used for the study of heredity were thus the latency index (tabl. 1 and 2). Both inbreds and hybrids showed significant genotypic differences and

TABLE 1

Ascospore test : Latency indexes of inbred lines. Means of 2 repetitions.

Test ascospores: Indices de latence des lignées parentales (moyennes de 2 répétitions).

\begin{tabular}{llll}
\hline Females & $(1)$ & B11A3 & 0.89 \\
& $(2)$ & 62 & 0.79 \\
& $(3)$ & SD & 1.27 \\
& $(4)$ & GH & 0.83 \\
& $(5)$ & GU & 0.78 \\
& $(6)$ & F10 & 0.61 \\
\hline Males & $(1)$ & HA61 & 1.08 \\
& $(2)$ & Rha274 & 1.03 \\
& $(3)$ & Rha266 & 1.01 \\
& $(4)$ & V135 & 0.81 \\
& $(5)$ & PAC1 & 0.94 \\
& $(6)$ & PRS5 & 0.93 \\
\hline \hline LSD (5\%) $=0.15$ & C.V. $=7.69 \%$ & \\
F genotypes $=11.99(11 / 11$ d.f. & & \\
F repetitions $=5.82(1 / 11 \text { d.f. })^{*}$ &
\end{tabular}

TABLE 2

Ascospore test. Latency indexes of hybrids and mean parental effects. Means of 2 repetitions.

Test ascospores: Indices de latence des hybrides

\begin{tabular}{|c|c|c|c|c|c|c|c|}
\hline$M^{F}$ & $\begin{array}{c}(1) \\
B 11 A 3\end{array}$ & $\begin{array}{l}\text { (2) } \\
62\end{array}$ & $\begin{array}{l}(3) \\
\text { SD }\end{array}$ & $\stackrel{(4)}{G H}$ & $\stackrel{(5)}{G U}$ & $\begin{array}{l}(6) \\
\text { F10 }\end{array}$ & $\bar{x}$ \\
\hline (1) HA61 & 1.12 & 0.99 & 1.17 & 1.16 & 0.91 & 0.97 & 1.05 \\
\hline (2) Rha274 & 1.01 & 0.97 & 1.05 & 0.98 & 0.83 & 0.92 & 0.96 \\
\hline (3) Rha266 & 0.92 & 0.83 & 1.00 & 0.83 & 1.02 & $(0.84)$ & 0.90 \\
\hline (4) V135 & 0.80 & 0.81 & 1.02 & 0.84 & 0.77 & 0.73 & 0.82 \\
\hline (5) $\mathrm{PACl}$ & 1.08 & 0.85 & 1.30 & 0.93 & 0.96 & 0.86 & 0.99 \\
\hline (6) PRS5 & 0.96 & 0.83 & 1.17 & 0.83 & 0.89 & 0.88 & 0.92 \\
\hline $\bar{x}$ & 0.99 & 0.88 & 1.11 & 0.93 & 0.91 & 0.86 & \\
\hline $\begin{array}{l}\text { LSD }(5 \%) \\
\text { LSD }(5 \%) \\
\text { F genotyp } \\
\text { F repetitio }\end{array}$ & hybrids & $\begin{array}{l}0.08 \\
\text { ffects }\end{array}$ & $\begin{array}{l}\quad \text { C.V. } \\
=0.04 \\
\text { d.f. })^{* *}\end{array}$ & $=5.4$ & $\%$ & & \\
\hline
\end{tabular}
(moyennes de 2 répétitions). 
TABLE 3

Ascospore tests - Estimates of heritability using the latency index.

Tests ascospore - Estimation de l'héritabilité à travers l'indice de latence.

1. Factorial analysis of variance on hybrids

Analyses using

\begin{tabular}{|c|c|c|c|c|c|}
\hline Female parents & Male parents & $\mathrm{F}_{\mathrm{F}}$ & $F_{M}$ & $F_{1}$ & $\mathrm{GCA} / \mathrm{SCA}$ \\
\hline 12345 & 123456 & $38.52^{* *}$ & $21.66^{* *}$ & $4.70^{* *}$ & 2.74 \\
\hline 123456 & 12456 & $39.60^{* *}$ & $31.16^{* *}$ & $3.59 * *$ & 4.49 \\
\hline \multirow[t]{2}{*}{12345} & 12456 & $36.67^{* *}$ & $22.94^{* *}$ & $3.62^{* *}$ & 4.05 \\
\hline & & & & Mean & 3.76 \\
\hline
\end{tabular}

$F_{F}=F$ female effect $-F_{M}=F$ male effect $-F_{I}=F$ interactions.

$\mathrm{GCA} / \mathrm{SCA}=\sigma^{2}$ general combining ability $/ \sigma^{2}$ specific combining ability.

2. Regression and correlation coefficients

\begin{tabular}{lcccc}
\hline \hline & $\mathrm{N}$ & $\begin{array}{c}\text { Regression } \\
\text { coefficient }\end{array}$ & $\begin{array}{c}\text { Correlation } \\
\text { coefficient }\end{array}$ & Determination \\
\hline Mid parent-hybrid & 35 & 0.90 & $0.76^{* *}$ & 0.58 \\
Inbred-hybrid mean & 12 & 0.40 & $0.83^{* *}$ & 0.69 \\
\hline
\end{tabular}

analyses of hybrids showed significant differences between parental effects with SD, the best female, $(\mathrm{I}=1.11)$ and HA 61, the best male, $(\mathrm{I}=1.05)$. Since the hybrid F10 Rha 266 was not tested, factorial analyses of variance were made excluding either one or other or both the parental lines. In table 3 , it may be noted that the $F$ values are very similar for the three analyses, greatest for the female parent effects but with considerable male effects and small but significant interactions. The ratio of general to specific combining ability varies but it is always largely superior to 1 , indicating that additive gene action is important.

The regression between the means of parents and their hybrids is highly significant. The regression coefficient $R$, an estimate of heritability (FALCONER, 1972), at 0.90, indicates that resistance and susceptibility vary in a similar manner in inbreds and hybrids. The correlation coefficient between inbreds and the means of their hybrids, $\mathrm{r}=0.83$ indicates that it is possible to predict the values of hybrids from their parents, with a determination of 0.69 .

\section{B. Semi-natural attack}

The results presented in tables 4 and 5 are ratios of the percentage of plants attacked per plot compared with those of the control, Rémil which flowered at the same time. The attack on Rémil was $15.7 \%$ when early flowering, $19.5 \%$ for mid flowering and $12.5 \%$ for late flowering. Significant block effects were also observed. This variation probably resulted from differences in spore density and numbers of irrigations, after flowering. There were significant genotypic differences among both inbreds and hybrids, although certain inbred lines, such as SD and GU, showed considerable variation. As with the ascospore test, there were significant differences
TABLE 4

Natural Sclerotinia attack on inbred lines. Means of 4 repetitions. The results are ratios:

$\%$ attack on inbreds

$\%$ attack on control with same flowering date

Attaques naturelles de Sclerotinia sur les lignées parentales Moyennes de 4 répétitions. Résultats exprimés en rapport :

$\%$ d'attaque sur la lignée

$\%$ d'attaque sur le témoin de même date de floraison

\begin{tabular}{llll}
\hline Females & $(1)$ & B11A3 & 1.43 \\
& $(2)$ & 62 & 1.57 \\
& $(3)$ & SD & 1.61 \\
& $(4)$ & GH & 3.60 \\
& $(5)$ & GU & 2.19 \\
& $(6)$ & F10 & 3.79 \\
\hline \multirow{2}{*}{ Males } & $(1)$ & HA61 & 1.22 \\
& $(2)$ & Rha274 & 1.96 \\
& $(3)$ & Rha266 & 1.82 \\
& $(4)$ & V135 & 1.46 \\
& $(5)$ & PAC1 & 0.69 \\
& $(6)$ & PRS5 & 1.23 \\
\hline \hline
\end{tabular}

$\operatorname{LSD}(5 \%)=1.51 \quad$ C.V. $=55.65 \%$

$\mathrm{F}$ genotypes $=3.16(11 / 33 \mathrm{~d} \text {.f. })^{* *}$

$\mathrm{F}$ repetitions $=10.70(3 / 33 \text { d.f. })^{* *}$

between general combining abilities (G.C.A.) with extremes of 0.80 for $\mathrm{PACl}$ and 3.07 for $\mathrm{GH}$. In the absence of 4 hybrids, factorial analyses were carried out on 7 different combinations of hybrids involving the maximum numbers of parents (tabl. 6). The results vary considerably according to combination but parental $\mathrm{F}$ values are always greater than interactions, which, in 2 cases, are not significant. The male $F$ value exceeds that of the female in 5 of 7 combinations. The G.C.A./S.C.A. ratio varies from 0.87 , indicating equal importance of additivity and interactions to 4.06 indi- 
TABLE 5

Natural Sclerotinia attack on hybrids and mean parental effects. Means of 4 repetitions.

The results are ratios:

$\%$ attack on hybrids

$\%$ attack on control with same flowering date

Attaque naturelle de Sclerotinia sur les hybrides.

Moyennes de 4 répétitions.

Résultats exprimés en rapport:

$\%$ d'attaque sur l'hybride

\% d'attaque sur le témoin de même date de floraison

\begin{tabular}{lccccccc}
\hline \hline M & $\begin{array}{c}(1) \\
\text { (1) HA61 }\end{array}$ & $\begin{array}{c}(2) \\
62\end{array}$ & $\begin{array}{c}(3) \\
\text { SD }\end{array}$ & $\begin{array}{l}\text { GH } \\
\text { (2) }\end{array}$ & $\begin{array}{c}(5) \\
\text { GU }\end{array}$ & $\begin{array}{l}\text { F10 } \\
\text { (2) }\end{array}$ & $\bar{x}$ \\
\hline (3) Rha274 & 0.49 & 1.05 & 1.08 & {$[3.78]$} & 2.46 & 2.21 & 1.84 \\
\hline (4) V135 & 2.54 & 2.01 & 1.55 & 2.33 & 2.58 & {$[1.76]$} & 2.13 \\
\hline (5) PAC1 & 0.31 & 1.45 & 0.71 & 1.52 & 0.47 & 0.35 & 0.80 \\
\hline (6) PRS5 & 1.38 & 0.82 & 1.09 & 3.63 & 1.79 & 1.58 & 1.72 \\
\hline $\bar{x}$ & 1.34 & 1.45 & 1.23 & 3.07 & 2.27 & 1.66 & \\
\hline \hline
\end{tabular}

LSD $(5 \%)$ hybrids $=0.92 \quad$ C.V. $=41.89 \%$

LSD $(5 \%)$ parental effects $=0.45$

$\mathrm{F}$ genotypes $=10.18(31 / 93 \mathrm{~d} . \mathrm{f} .)^{* *}$

$\mathrm{F}$ repetitions $=10.00(3 / 93 \text { d.f. })^{* *}$ cating preponderant additive effects; in 5 of 7 combinations additivity appears more important than interactions.

The mid parent-hybrid regression is significant, with a regression coefficient of $\mathrm{R}=1.21$, which results from the fact that there are greater differences in attack between hybrids $(0.31$ to 5.81$)$ than between inbred lines $(0.69$ to 3.60$)$. The mid parent-hybrid and inbred-mean hybrid correlation coefficients, both $r=0.49$ are significant, but at lower levels than for the ascospore tests, giving determinations of only $24 \%$.

\section{Correlation between the ascospore test and natural attack}

For the 32 hybrids studied by the ascospore test and by natural attack trials, the correlation between the latency index of the test and the \% natural attack (as a proportion of the control) was $r=-0.57$ (HS). For the 12 inbred lines $r=-0.52(\mathrm{~S})$. Genotypes with the greatest delay in symptom appearance after the ascospore test are thus those which show the lowest frequencies of attack under natural conditions.

\section{DISCUSSION}

The ascospore test was carried out under very favorable conditions, such that most plants were attacked, and so it provided representative latency indexes for the genotypes studied. There are significant genetic differences between hybrids, with significant general combining abilities, and significant differences between per se values for inbred lines. The close correlation between inbred lines and their hybrids $(r=0.83)$ indicates that

TABLE 6

Natural infection - Estimates of heritability.

Infection naturelle - Estimation de l'héritabilité.

1. Factorial analysis of variance on hybrids

Analyses using

\begin{tabular}{|c|c|c|c|c|c|}
\hline Female parents & Male parents & $F_{F}$ & $F_{M}$ & $F_{I}$ & GCA/SCA \\
\hline 25 & 123456 & $9.16^{* *}$ & $6.18^{* *}$ & $2.07(\mathrm{NS})$ & 4.06 \\
\hline 245 & 13456 & $13.80^{* *}$ & $22.64^{* *}$ & $4.66^{* *}$ & 1.81 \\
\hline 2345 & 1356 & $6.97^{* *}$ & $6.20^{* *}$ & $3.09 * *$ & 0.87 \\
\hline 2456 & 1456 & $17.61^{* *}$ & $44.77^{* *}$ & $5.26^{* *}$ & 3.03 \\
\hline 1235 & 12356 & $4.64 * *$ & $6.42^{* *}$ & $1.60(\mathrm{NS})$ & 2.89 \\
\hline 12345 & 1356 & $5.64^{* *}$ & $5.64^{* *}$ & $2.62^{*}$ & 1.59 \\
\hline \multirow[t]{2}{*}{123456} & 156 & $10.58^{* *}$ & $10.58^{* *}$ & $17.29^{* *}$ & 0.94 \\
\hline & & & & Mean & 2.17 \\
\hline
\end{tabular}

$F_{F}=F$ female effects $-F_{M}=F$ male effects $-F_{I}=F$ interactions.

$\mathrm{GCA} / \mathrm{SCA}=\sigma^{2}$ general combining ability $/ \sigma^{2}$ specific combining ability.

2. Regression and correlation coefficients

\begin{tabular}{lcccc}
\hline \hline & $\mathrm{N}$ & $\begin{array}{c}\text { Regression } \\
\text { coefficient }\end{array}$ & $\begin{array}{c}\text { Correlation } \\
\text { coefficient }\end{array}$ & Determination \\
\hline Mid parent-hybrid & 32 & 1.12 & 0.49 & 0.24 \\
Parent-mean hybrid & 12 & 0.43 & 0.49 & 0.24 \\
\hline
\end{tabular}


with this test, it is possible to measure the same resistance factors in both types of material, and that the reaction of hybrids can be predicted quite satisfactorily from those of their parents.

The observations of natural attack, after irrigation during flowering, demonstrated significant differences between genotypes, independant of their flowering dates. The data from the hybrids indicated that although some interactions occur, parental effects are of greatest importance. Observations on hybrids provided no special problems, whereas on inbred lines, difficulties were met in their lack of vigour, branching and rapid desiccation. These problems may be a reason, as opposed to a genetical basis, for the rather weak correlation between observations on parents and their effects in hybrids. Results of this type have been observed over several years (ROBERT et al., 1987) and it appears reasonable to suggest that observations of natural capitulum attack should be confined to hybrids or similar genotypes.

The results presented here indicating that the ascospore test is significantly correlated with field attack corroborate earlier observations (TOURVIEILLE \& VEAR, 1984). ROBERT et al. (1987) demonstrated that the mycelium test on capitulum was also significantly correlated with field attack. However it is interesting to note that, for the same hybrid genotypes, the present results concerning the ascospore test and the results concerning the mycelium test reported by ROBERT et al. (1987) are not significantly correlated $(\mathrm{r}=0.27 \mathrm{~N}=32)$. Thus it may be concluded that the 2 tests measure different resistance factors, both contributing to field behaviour, that the 2 tests are complementary and should, if possible, be used together in breeding programmes. The importance of field observations remains that it is possible to observe a much larger number of hybrid genotypes than in tests and that occasional genotypic combinations occur, whose resistance is not explained by any present testing method (ToURVIEILLE, unpublished).

As with the results of the mycelium tests (ROBERT et al., 1987), the ascospore test and observations of natural attack indicate that additive gene effects are generally more important than dominance although some hybrid combinations do show significant specific combining abilities. This could perhaps be due to the presence of genes affecting Sclerotinia resistance which are absent from most of the lines. The results agree with those of Fuller et al. (1984) for Sclerotinia on beans although not with these of PIRvU et al. (1985) on sunflower but where no irrigation was used. In all cases resistance appears to be polygenic. The closest correlation between parents and hybrids, observed with the mycelium test $(r=0.92)$, may be due to the fact that the character observed, rate of mycelium extension on the capitulum parenchyma, is simpler than in the case of the ascospore test $(\mathrm{r}=0.83)$ or natural infection $(\mathrm{r}=0.49)$ where many different capitulum tissues are involved.

Results in recent years (BAZZALO et al., 1985; Thuault \& TourvieIlle, 1987 ; Hemery, 1987) of biochemical studies indicate that the content of total or specific phenol compounds may be related to Sclerotinia resistance in both sunflower capitula and stems. Although these contents could be under relatively simple genetic control, it appears that many other tissular factors are involved in resistance and breeding programmes must take them all into account. Programmes must be such as to favorise the concentration of a large number of useful genes in one genotype. Recurrent selection with the use of several resistance tests, both to increase the frequency of favorable genes in the population and during the selection of inbred lines, with final checks of resistance levels of hybrids under natural attack, appears to provide a reasonable solution.

Reçu le 6 novembre 1987. Accepté le 6 avril 1988.

\section{REFERENCES}

Bazzalo M., Heber E., Delporo de Martinez M., Caso O., 1985. Mecanismos de resistencia en Helianthus annuus $L$. frente il la podredumbre basal (Sclerotinia sclerotiorum (L.) de By.). Proc. Ith Int. Sunflower Conference, Mar del Plata, Argentina, 605-610.

Falconer D. S., 1972. - Introduction à la génétique quantitative. Masson et Cie, 284 p.

Fuller P., Coyne D. P., Steadman J. R., 1984. - Inheritance of resistance to white mold disease in a diallel cross of dry beans. Crop Science, 24, 929-933.

Hemery M. C., 1987. - Recherche de marqueurs phénoliques pour la résistance du tournesol au Sclerotinia sclerotiorum. DEA Université Blaise Pascal, Clermont-Ferrand, France, 31 p.

Lamarque C., Tourvieille D., Regnault Y., Pierre J. C., 1985. - Les problèmes posés par la lutte chimique contre le Sclerotinia sclerotiorum sur capitule de tournesol. In Premières Journées d'études sur les maladies des plantes, A.N.P.P., 2, 359-367.

Pirvu N., Vranceanu A. V., Stoenescu F., 1985, - Genetic mechanisms of sunflower resistance to white rot (Sclerotinia sclerotiorum (Lib.) de Bary). Z. Pflanzenzüchtng, 95, 157-163

Robert N., Vear F., Tourvieille D., 1987. — L'hérédité de la résistance au Sclerotinia sclerotiorum (Lib.) de Bary chez le tournesol. I. Etude des réactions à 2 tests mycéliens. Agronomie, 7, 423-429.

Says-Lesage V., Tourvieille D., 1988. - Recherche de sites de pollution et d'infection des fleurons de tournesol in situ par des spores de Sclerotinia sclerotiorum. Inf. tech. CETIOM, 102 (sous presse).
Thuault M. C., Tourvieille D., 1988. - Etude du pouvoir pathogène de 8 isolats de Sclerotinia appartenant aux espèces $S$. sclerotiorum, $S$. minor et $S$. trifoliorum sur tournesol. Inf. tech. CETIOM (sous presse).

Tourvieille D., Vear F., 1984. - Comparaison des méthodes d'estimation de la résistance du tournesol à Sclerotinia sclerotiorum (Lib.) de Bary, Agronomie, 4 (6), 517-525.

Vear F., Guillaumin J. J., 1977. — Etude de méthodes d'inoculation du tournesol par Sclerotinia sclerotiorum et application à la sélection. Ann. Amélior. Plantes, 27 (5), 523-537.

Vear F., Tourvieille, 1984a. - Recurrent selection for resistance to Sclerotinia sclerotiorum in sunflowers using artificial infections. Agronomie, 4 (8), 789-794.

Vear F., Tourvieille D., 1984b. - Sclerotinia sclerotiorum sur tournesol. Différences de sensibilité variétale et méthodes de sélection. Conférence du 28 février 1984, I.N.R.A. Clermont-Ferrand, 106 p.

Vear F., Tourvieille D., 1985. - Resistance to Sclerotinia sclerotiorum in sunflowers. Proc. 11th Int. Sunflower Conf., Mar del Plata, Argentina, $357-362$

Vear F., Tourvieille D., 1987. - Le jugement d'hybrides de Tournesol vis-à-vis d'infection naturelle du Sclerotinia sclerotiorum sur capitule. Inf. tech. CETIOM, 99, 9-14. 